'A jack of all trades' - The role of PIs in the establishment and management of collaborative networks in scientific knowledge commercialisation

\title{
Paper accepted for
}

special edition of the Journal of Technology Transfer on the growing role of PIs as science, technology and market shapers.

September 2012

\section{Dr Diana Nadine Boehm*}

Dublin City University

LInK Research Centre

DCU Business School

Dublin 9

Tel: (01) $700-6877$

diana.boehm@dcu.ie

* Corresponding author

\section{Dr Teresa Hogan}

Dublin City University

LInK Research Centre

DCU Business School

Dublin 9

Tel: (01) $700-8082$

teresa.hogan@dcu.ie 


\title{
'A jack of all trades' - The role of PIs in the establishment and management of collaborative networks in scientific knowledge commercialisation
}

\begin{abstract}
The commercialisation of scientific knowledge has become a primary objective for universities worldwide. Collaborative research projects are viewed as the key to achieving this objective, however, the role of Principal Investigators (PIs) within these complex multistakeholder research projects remains under researched. This paper explores how networks in the scientific knowledge collaboration process are initiated and maintained from a multistakeholder perspective. It is based on case study evidence from 82 stakeholders in 17 research collaboration projects in Irish and German universities, which provides for a holistic view of the process, as opposed to prior research which has tended to report findings based on the analysis of one or two stakeholders. It finds that PIs play a lead role in establishing and managing stakeholder networks. This finding is unanimous for all stakeholders, irrespective of research centre size, type and geographical location. Not unlike the entrepreneur, the PI has to be 'a jack of all trades', taking on the roles of project manager, negotiator, resource acquirer as well as, the traditional academic role of Ph.D. supervision and mentoring. The findings suggest that PIs are better placed than Technology Transfer Office (TTO) managers to act as boundary spanners in bridging the gap between science and industry.
\end{abstract}




\section{Introduction}

At present, there would appear to be inconsistent views in the literature on the role of TTOs versus PIs in the scientific knowledge collaboration process (Rothaermel et al. 2007). In some sense this confusion is not surprising, since the findings are likely to vary depending on who you ask. On the one hand, scientists and industry partners will often criticise government agencies and TTOs as being well meaning but ineffective. On the other hand, industry partners and TTOs often criticise academics for their lack of understanding of the commercial world. Most studies still look at dyadic relationships between university and industry (Plewa and Quester 2008). While, some take the government into account (Boardman 2009; Boardman and Corley 2008), only a few seek to incorporate diverse actors to study multilevel interaction (Adler et al. 2009). Complex research issues like scientific knowledge collaboration processes are better addressed by focusing on all agents involved. The paper is novel in that it adopts a stakeholder perspective on collaborative research. A holistic perspective on process of initiating and managing science-industry collaborations is derived from interviewing the PIs and key stakeholders including TTO managers, universityresearch-centre managers or commercialisation managers, industry partners, and government agents.

As the research design specifically included all stakeholders' views, we can unequivocal conclude that the PI plays the lead role in establishing and managing stakeholder networks. With 79 out of 82 respondents in agreement this view is shared across stakeholders, irrespective of research centre size, type and geographical location. Not unlike the entrepreneur, the PI has to be a 'jack of all trades' taking on the roles of project manager, negotiator, and resource acquirer, as well as, the traditional academic role of Ph.D. supervision and mentoring. The findings suggest that PIs are better placed than TTO managers to act as boundary spanners in order to bridge the gap between science and industry.

The paper is structured as follows. Section 2 looks at the contributions from the literature on stakeholders involved in the commercialisation of scientific knowledge, focusing on the role of PIs and TTOs. Following the theoretical overview, section 3 elaborates the case study methodology. The fourth section presents the findings from the qualitative analysis. Section 5 provides a discussion and managerial implications. 


\section{The role of stakeholders in the commercialisation process}

Collaborative research refers to projects where universities and businesses work together on shared problems (Martinelli et al. 2008). Collaborations can be defined as "all forms of agreements between firms, universities, and research institutes whereby two or more organisations share the commitment to research a common goal by pooling their resources and co-ordinating their activities" (European Commission 2002 p15). These networks involve multiple stakeholders, including PIs, centre managers or commercialisation managers, TTO managers, industry partners and government funding agents. This paper focuses on the role of two of these stakeholders, namely TTOs and PIs and investigates how and by whom science-industry collaborations are initiated and managed.

\subsection{The role of the PI}

Different stakeholders will have both complementary and conflicting motives for engaging in collaborative networks. According to research, scientists' major motive for pursuing commercial opportunities is recognition within the scientific community (Siegel 2003; Siegel et al. 2003; Siegel et al. 2004). For some scientists, however, personal satisfaction and solving societal problems are considered to be more important than financial rewards (Goktepe-Hultèn 2008).

Several authors argue (Radosevitch 1995; Birley 2002, Fontes 2003) that an entrepreneurial mind-set differentiates inventors from other academics, as people who produce commercial results differ from those who generate academic ones (Ambos et al. 2008). This leads to discussions about whether academics are 'entrepreneurial academics' or 'academic entrepreneurs'. The former being described as a pioneering faculty member and the latter being described as the exemplary start-up entrepreneur (Martinelli et al. 2008). The choice to either take the entrepreneurial route or TTO/collaborative route depends on commercial motives (entrepreneurial route) or research related motives (collaborative projects and TTO route) (Audretsch et al. 2006). Affiliation with a network and personal relationships are important when taking the entrepreneurial route through spinning out a company (Roberts 1991; Meyer 2003; Goktepe-Hultèn 2008), but can also increase the tendency to commercialise research through the TTO route (Audretsch et al. 2006). Oliver (2004) finds that scientists involved in collaboration with industry are more likely to submit patent 
applications than scientists who are not. Research on different commercial routes, across scientific disciplines indicate that scientific knowledge collaboration is dependent on network participation by scientists but also highlights the necessity of diverse incentives.

\subsection{The role of the TTO}

Current policy is based on the belief that the establishment of TTOs enables successful transfer of technologies and creates the "formal gateway between university and industry" (Rothaermel et al. 2007 p740). In many cases governments provide direct and indirect support funds for TTOs (OECD 2002, Forfas 2010) to enable successful knowledge transfer and commercialisation. The role of the TTOs is often referred to as bridging the gap between the university and industry (Siegel et al. 2004, Wright et al. 2008). The views on the role of the TTOs are, however, rather inconsistent. Some authors argue that the TTOs are responsible for establishing links between university and industry (Jones-Evans and Klofsten 1999, Siegel et al. 2004, Debackere and Veugelers 2005) while others argue that a TTO's marketing activities are only needed where existing links are weak and all participants are not already rooted in personal or broader scientific networks (Colyvas et al. 2002). Lockett et al. (2005) argue that incentives should be offered to TTO personnel, and not the scientist, so as to encourage more commercial activity. Goldfarb and Henrekson (2003) argue that a top-down policy (in Sweden) is discouraging commercialisation and that the US is in a much more favourable position as there is competition among universities for funding and scientists.

A lack of management skills (Spilling 2004, Wright et al. 2008), insufficient IP, market and entrepreneurial experiences (Lambert 2003, Hall 2004, Zhao 2004) and bad staffing practices (O'Shea et al. 2004, O'Shea et al. 2008) were found to be operational barriers to scientificknowledge commercialisation and reflect quality issues within TTOs.

The efficiency and acceptance of TTOs vary from country to country. TTOs in the US seem to be more successful than in the UK (Chapple et al. 2005). In Germany, TTOs and regional patent agencies do not appear to be widely accepted by academia and industry (Kienbaum 2006, Sellenthin 2009). In Ireland, a recent survey found that whilst TTO were adequately staffed, they did not have adequate time to build network relationships (Forfas 2010). It also recommended the personnel needed to be up-skilled (Forfas 2010). 
In sum, the TTO's role as boundary spanner has been researched with conflicting findings. The role of the academic as the bridge between industry and academia is, however, not clearly set out. Given the importance of networks in the theoretical frameworks, there is a need for a better understanding of (a) who enables effective interaction and (b) how stakeholder relationships are managed in scientific knowledge collaboration networks.

\section{Methodology}

The study uses a qualitative case-research approach to examine by whom relationships within collaborative networks are established and managed. Case research is believed to be more appropriate as the analysis of stakeholder relationships is best examined in a real life context (Perry 2001). In addition, qualitative data provide for deeper insight into stakeholder relationships as they involve complex social processes that quantitative data cannot disclose (Eisenhardt and Graebner 2007). A holistic perspective on the establishment and management of relationships within collaborative networks is derived from interviewing 82 stakeholders in 17 research-collaboration projects. These 17 research-collaboration projects within 17 research organisations constitute the cases of the study.

Following Yin (2009) and Eisenhardt (1989) the cases are selected considering literal and theoretical replication. Replication logic serves to identify root causes of the performance differential and, thus, possibilities for further research. It also serves to identify similar research results to enable theory building (Eisenhardt 1989). The selection is bases on two aspects which are central to the analysis and are discussed in the next section.

\subsection{Research Context}

The first aspect involves a comparison between Germany and Ireland. The second aspect compares excellence centres with faculty-based centres. Turning firstly to the national comparison, Germany and Ireland have been chosen as their policy initiatives are quite similar with regard to creating centres of excellence. The two countries have, however, different economic and financial infrastructures. Germany ranks among the leading economies of the world and has a strong tradition of university-industry collaboration. It has one of the highest levels of R\&D expenditure in Europe, with R\&D expenditure of $2.63 \%$ of GDP in 2008 (Eurostat 2012). This compares to Ireland's R\&D expenditure of $1.43 \%$ of GDP in 2008, which, although catching up, is still well below the expected EU target (Forfas 
2009). In Ireland, the industry context is primarily based upon multi-national subsidiaries which are generally less embedded in the local economy. The challenge is to encourage multinationals to undertake more research in Ireland. In this respect, one would expect that Ireland could learn some lessons from Germany's long tradition of university-industry collaborations. Nonetheless, a recent report by the Commission of Experts for Research and Innovation (2009) revealed that knowledge and technology transfer in Germany is not perfect either. Germany, although having a long established and successful past in contract research, lacks the know-how of strategic partnerships for business-university collaborations.

Controversially, a recent study by Jordan and O'Leary (2007) indicated that higher education institutes contribute less to the innovation output than expected. Germany, on the other hand, continues to outrank Ireland in relation to university-industry collaborations as measured by the global innovation index (INSEAD 2011). Given the relatively similar cultures, this anomaly provides an interesting and relevant backdrop to this study's comparison of the two countries' systems.

Secondly, the performance of externally funded designated centres of excellence and facultybased research centres are compared. Excellence centres in both countries are funded by dedicated government initiatives and are allocated on average $€ 5$ million per year. They were introduced to create excellence in research and to form interdisciplinary research hubs for collaboration and networking. The funding incorporates funding for research as well as administration and equipment. These initiatives served to place universities at the centre of the science system. For the Irish excellence centres (Centres for Science Engineering and Technology or CSET) industry involvement is a requirement for funding. While industry involvement is considered desirable and plays an important role, the main aim of the German excellence centres is to improve cutting-edge research in Germany and to improve its international competitiveness. Faculty-based research centres, on the other hand, are research centres or research of faculties which are located within a faculty and are not funded through a specific policy initiative. They acquire their funding by applying for government or EU grants and are, thus ordinarily less well equipped in terms of administration, support structures or equipment than centres of excellence. Therefore, one would expect that excellence centres should outperform faculty-based centres. This study does not, however, 
look at quantitative output-metrics that such centres create. Rather, it looks at the impact of research centre type on the dynamics of a collaborative network.

By addressing these comparisons nine excellence research centres and eight faculty-based centres located in Ireland and Germany were identified. The cases were selected from universities that had provided both, excellence centres as well as faculty-based research.

\begin{tabular}{|c|c|c|c|c|}
\hline & \multicolumn{2}{|l|}{ Ireland } & \multicolumn{2}{|l|}{ Germany } \\
\hline & Trinity College & $\begin{array}{l}\text { Dublin City } \\
\text { University }\end{array}$ & $\begin{array}{l}\text { Ludwig } \\
\text { Maximilian } \\
\text { University }\end{array}$ & $\begin{array}{l}\text { Technical } \\
\text { University } \\
\text { Munich }\end{array}$ \\
\hline \multirow[t]{2}{*}{$\begin{array}{l}\text { Excellence } \\
\text { Centre }\end{array}$} & $\begin{array}{l}\text { CRANN - } \\
\text { Centre for } \\
\text { Research on } \\
\text { Adaptive } \\
\text { Nanostructures } \\
\text { and Nano } \\
\text { Devices }\end{array}$ & $\begin{array}{l}\text { BDI - } \\
\text { Biomedical } \\
\text { Diagnostics } \\
\text { Institute }\end{array}$ & $\begin{array}{l}\text { MAP - Munich } \\
\text { Advanced } \\
\text { Photonics } \\
\text { NIM - Nano } \\
\text { Initiative } \\
\text { Munich }\end{array}$ & $\begin{array}{l}\text { COTESYS - } \\
\text { Cognition for } \\
\text { Technical } \\
\text { Systems }\end{array}$ \\
\hline & $\begin{array}{l}\text { CTVR - Centre } \\
\text { Telecommunica } \\
\text {-tions and Video } \\
\text { Research }\end{array}$ & $\begin{array}{l}\text { CNGL - Centre } \\
\text { for Next } \\
\text { Generation } \\
\text { Localisation }\end{array}$ & $\begin{array}{l}\text { CIPSM - Centre } \\
\text { for Integrated } \\
\text { Protein Science }\end{array}$ & $\begin{array}{l}\text { Universe } \\
\text { Cluster - Origin } \\
\text { and structure of } \\
\text { the universe }\end{array}$ \\
\hline \multirow{2}{*}{$\begin{array}{l}\text { Faculty-based } \\
\text { centre }\end{array}$} & $\begin{array}{l}\text { TCIN - Trinity } \\
\text { College Institute } \\
\text { of Neuroscience }\end{array}$ & $\begin{array}{l}\text { RINCE - } \\
\text { Research } \\
\text { Institute focused } \\
\text { on engineering } \\
\text { Technologies }\end{array}$ & $\begin{array}{l}\text { CeNS - Centre } \\
\text { for Nano } \\
\text { Science }\end{array}$ & $\begin{array}{l}\text { Faculty for } \\
\text { Aerodynamics }\end{array}$ \\
\hline & $\begin{array}{l}\text { Trinity centre } \\
\text { for } \\
\text { Bioengineering }\end{array}$ & $\begin{array}{l}\text { ICNT - } \\
\text { International } \\
\text { Centre for } \\
\text { Neuro- } \\
\text { Therapeutics }\end{array}$ & $\begin{array}{l}\text { BioImaging } \\
\text { Centre }\end{array}$ & $\begin{array}{l}\text { Faculty for } \\
\text { Flight System } \\
\text { Dynamics }\end{array}$ \\
\hline
\end{tabular}

Table 1: Case study selection

By selecting the specific cases and considering multiple heterogeneous sources this research design is facilitating analytical generalisation to build theory.

\subsection{Data Collection}

The data is based on 82 semi-structured interviews of which 75 were face-to-face interviews and 7 were telephone interviews. The interviews were conducted with 25 PIs, 13 researchcentre managers or commercialisation managers, 13 TTO managers, 22 industry partners and 9 government agents who participated in collaborative projects. All government agents were 
responsible for multiple centres. Where they covered two projects, they were interviewed once but were asked to discuss both projects. The same applied for the 4 TTOs of the 4 universities. Interviews lasted between 45 and 60 minutes.

A semi-structured interview protocol was used to guide the interviews. Firstly, stakeholders were asked to outline their backgrounds and briefly summaries the projects. While this got respondents talking, the interview protocol was used as a guide to structure the interviews. Questions were not asked in any particular order to facilitate a conversion with the interviewees. Where a respondent mentioned a particular research issues probe questions were asked to explore in more detail how and why these issues were of importance. In order to reveal why universities are used the participants were asked to reflect on the following topics: (a) how projects are initiated, (b) project objectives and (c) differences in the initiation process for different projects.

The respondents were questioned on whether they have or will undertake another project with current partners and were asked to explain their answers. They were invited to make suggestions in relation to what the individual players can do to encourage additional projects. They were also invited to reflect on (a) how they evaluate the success or failure of a project, (b) what sort of information they shared with the partners and (c) whether they shared all information. Further questions were asked in relation to (a) the establishment and management of relationships and (b) how a collaborative network of relationships is being facilitated/developed. Finally, they were asked to (a) reflect on the barriers and enablers to collaborative relationships and commercialisation in general and (b) the benefits of network involvement. In order to ensure validity we followed Perkmann and Walsh's (2009) methodology and asked for facts, to reduce cognitive bias and to limit impression management. The identification of specific projects facilitated this process. Participant confidentiality was assured.

\subsection{Case study analysis}

Qualitative data analysis starts during the data collection phase (Rocks et al. 2007). Comments and ideas that arose during each interview were summarised separately. All interviews were read by the interviewer in order to allow for interpretative flexibility and universal understanding. General expressions and similar description for the same meaning 
were identified. Data and summarised notes were reduced into categories (Miles and Huberman 1994, Glaser and Strauss 1967, Voss et al. 2002). The interview transcripts were then coded accordingly and meaning units extracted. The primary codes included text extractions referring to the use of the universities, relationship management, and factors and barriers. When all transcripts had been coded, each code was read again. Some of the codes had similar meanings or referred to more than one code. In re-reading the transcripts, subcategories emerged, similar categories were combined or others split up until everything had been categorised. In addition, N-Vivo was used to check and ensure that all relevant aspects had been identified. After the data was reduced to categories, the data was displayed to enable conclusion and verification drawing (Voss et al. 2002).

\begin{tabular}{|c|c|c|}
\hline Constructs $-1^{\text {st }}$ coding & Category $-2^{\text {nd }}$ coding & Category $-3^{\text {rd }}$ coding \\
\hline \multirow{7}{*}{ Use of university } & \multirow{4}{*}{ Industry contacts University } & Experience \& Knowledge \\
\hline & & Reputation \\
\hline & & Willingness of the PI \\
\hline & & Existing contacts \\
\hline & \multirow{2}{*}{ University contacts Industry } & Existing contacts \\
\hline & & Interest \\
\hline & TTO contacts Industry & \\
\hline \multirow{5}{*}{ Relationship management } & \multirow{4}{*}{ Role of PI } & Project manager \\
\hline & & Negotiator \\
\hline & & Resource acquirer \\
\hline & & Traditional academic role \\
\hline & Role of TTO & IP Protector \\
\hline \multirow[t]{2}{*}{ Factors } & Build network & \\
\hline & Importance of relationships & \\
\hline Barrier & TTO & \\
\hline
\end{tabular}

\section{Table 2: Codes and categories}

It is believed that the a priori selection of cases, based on analytical replication, guides the analysis (Eisenhardt 1989, Yin 2009). Within-case as well as cross-case analysis enables the researcher to view evidence from different perspectives. In order to present the empirical evidence and build theory it is recommended to compare the data with existing literature and analyse it in form of a dialogue between data and theory (Eisenhardt 1989, Halinen and Tornroos 2005, Eisenhardt and Graeber 2007, Yin 2009).

Eisenhardt and Graebner (2007) recommend the use of highly knowledgeable interviewees who view the researched phenomena from multiple perspectives as this helps to avoid bias. The multi-stakeholder approach enables the analysis of the true value of all stakeholders' 
roles. While it is acknowledged that qualitative analysis does not account for statistically significant results, a multi-stakeholder analysis will, if the stakeholders agree on certain topics irrespective of size, type or location of the centre, inform a general understanding. The design facilitates analytical generalisation as it refers to generalisation from empirical observations to theory, rather than a population (Yin 2009, Gibbert et al. 2008).

\section{Case study findings}

\subsection{The initiation of collaborative relationships and networks}

When looking at the establishment, management and maintenance of science-industry collaborations it is important to look at the reason for initiating relationships and by whom they are initiated. Collaborative networks, cooperative relationships and, above all, strong prior relationships between organisations impact on the successful transfer of knowledge (Harmon et al. 1997). Such networks influence identification of opportunities, entrepreneurial decision-making and access to resources. The case study findings reinforce this perspective. Fifteen out of 22 industrial partners explained that being part of a network is important not only for access to knowledge but also for generating and evaluating better ideas. This view is shared by ten PIs and all TTO managers.

Access to resources was the most common reason for collaborating given by PIs. They stated that is very important for them to get funding for their research, particularly in Ireland where industry collaboration has increasingly become a prerequisite to access government funding schemes. German PIs also mentioned the importance of access to additional funding. Access to funding is provided by industry partners, national governments and the EU. The empirical evidence shows that industry partners make further investments as a result of satisfactory relationships and continue collaborating with other partners.

It is not just academics that see access to resources as an important part of forming and developing collaborations. Industry partners also acknowledged the benefits of having access to financial resources and the infrastructure in university laboratories. These benefits relate to the ability to jointly finance equipment or researchers, get government and EU funding, and use existing facilities. 
In terms of who initiates the relationships, the findings show that both industry and university partners start relationships. The PIs play an important part in the initiation of these relationships. The TTOs, on the other hand, are hardly ever seen as the initiator or the point of contact for industry partners. The manager of a German multinational stated that she rarely gets in contact with the TTOs and that the TTOs are not normally responsible for initiating the initial contact. She further explained that she prefers having direct contact with the scientists. Similarly, for a German academic the TTO did not play a significant role;

"I guess, if you put it in percentages, that they [TTO] would not be able to account for $10 \%$ of newly established contacts. I mean it is probably even less than that...they are not the driving force, certainly not."

The story is similar in Ireland where a centre manager (and lead PI) stated that:

'the PI can be part of the establishment...you just can't have someone else establish it who doesn't know the nitty gritty of the research...I don't think it works any other way."

The involvement of the PI in the initiation of a relationship was confirmed by 79 out of the 82 participating stakeholders (including TTO managers). The PI's reputation is the reason for the initial contact. The reputation of the PI is a factor used by industrial partners when choosing a research centre. One PI, (and centre manager), stated that "when you are good, you catch people's attention and then people will come to you, you don't need any help". This is not only the academic point of view, industry also acknowledges this fact. The R\&D manager of a German multinational company reinforces this by declaring:

"it is not about universities; it is about professorships. I am not looking where a good university is, but it is a matter of where is the professor...I am looking for professors and what they know...we are looking around the world to figure out who studies a certain topic and then we get in contact with a few locations to just see who is doing what. So it is not about universities. It is always about people".

This finding implies that it is important for PIs to publish in high ranking journals, attend conferences to disseminate their research and build their reputations. The Government also requires high quality research from the PIs, as continuous funding of the centre is dependent on the quality of the PI's work. An Irish Government agent noted: 
"a lot of it is down to the quality of the work they [PIs] do. If a centre isn't producing quality work and it isn't internationally recognised as a leader in its field, then, we would have to think very carefully about whether we want to continue funding it".

This indicates that the PI is not just accountable for his or her own reputation but that of the centre as well, which in turn enhances the relationship with industry and the State.

Furthermore, there was consensus that the PI has to show a willingness or desire to collaborate in order for industrial partners to consider working with them and therefore the centre. A German TTO manager referred to the issue as follows:

"As a matter of principle and what is elementary to transferring or commercialising knowledge is a fundamental willingness to continue working on a certain topic and not to say: Great I have a patent and now I'll do something else".

An Irish Government agent confirmed this by saying that "there's no point if the technology is good but the people aren't interested in doing commercialisation". This is not only a view shared by the government and TTO managers but was also expressed by 15 out of 22 industry partners who pointed out that this was one of the most important issues for them.

\subsection{Management and maintenance of collaborative relationships}

According to the literature, a TTO's remit is to manage the transfer of knowledge by scouting IP and negotiating IP deals and building and managing links with industry (Siegel et al. 2004). When asked to explain the stability of a relationship with a university research centre a German industry partner said that "relationships always depend on people and their relations with each other". The case study findings are, however, close to unanimous with regard to centrality of the PI's role in the management of relationships over that of TTOs. An alternative to the PI-lead management structure was a team-lead management structure proposed by a small number of recently appointed commercialisation managers in Ireland. The importance of the PI in managing the relationships, however, was pointed out by other Irish commercialisation managers. One stated:

"at the end of the day somebody has to be the leader. There always has to be a leader and typically within [the centre] the leader is one of the academic PIs. So I guess in terms of ensuring that the projects are managed appropriately, really, it is the PI should be taken the responsibility for that". 
Another Irish industry partner from a multinational company said:

"I guess it's just people building relationships and experience. So if you have some rocky patches along the way and you see how people deal with those and how we resolve those... you can see that the relationship works."

He further acknowledges that it is the lead PI from the research centre that manages and coordinates these relationships. The management task is confirmed by 20 PIs who acknowledge their involvement in managing relationships. One German PI explained that he is not involved in day-to-day research activities as much as he would like as he has to take care of upcoming communication and operational problems. He has to act as a guardian to evaluate and reconcile mutual interests. Similarly, another German PI said that he acts as a "mediator, sort of a scientific pastor" to enable reciprocal benefits from the relationship.

It is interesting that the TTO's role in managing relationships is less important. Almost all industry contacts confirmed that the collaboration and on-going contact is with the PIs and not the TTO. A German faculty PI summarised the issue as follows:

"I only do research $5 \%-10 \%$ of my time. Of the 35 people I have, only six are funded by the State. The rest, that is 29 , are funded through third level funding, of which 23 are funded through industry third level funding. That means you can view it as a small business. I have to jump around quite a bit and you have to be agile when you are talking directly with people, when you establish mutual trust and then in a sense central services [TTOs] are toxic. They are good when you need some support information but if you have to use them, and then others think for you, and even if they mean it well, do things that do not serve the purpose and without consultation, then they are crap".

Another PI from an excellence centre in Germany said that networks exist without such overarching constructs and that their only function is to motivate and educate some scientists with respect to potential commercialisation. This issue is further enforced by a government agent who believed:

"we do not need intermediaries, but a telephone number, which is lying somewhere on an industrial partners desk, who, if he has a question, should call the professor and that professor has to pick up the phone and not some kind of technology transfer person, who after all, can only convey the question... we do not need intermediaries, but the direct contact." 
In Ireland, the remit and role of the TTO is perceived similarly. The manager of an excellence centre stated:

\begin{abstract}
"engaging with industry, creating really a vehicle for the research that goes on within a school or within a faculty to be contextualised for industry; if you want to do that you need the centre to have...its own business development people, its own intellectual property people, its own funding people. We duplicate a lot of the functions that exist across the college because we need to operate effectively, we have to have the local resource here. And I think that's absolutely the model that's needed if you want to create a critical mass of researchers that are going to engage effectively with industry."
\end{abstract}

In effect, TTO managers endorse this view by agreeing that the "best relationships come from the academics themselves". Similarly, another TTO manager confirmed:

"professors who have top-class industry cooperation, do it themselves...I mean they look after their contacts and take care of the technology transfer and the closure of projects themselves".

Evidence from the case studies presented here suggests that the PIs are responsible for the initiation, management and maintenance of relationships and that the TTOs act as an accompanying service in relation to IP issues. This finding is further affirmed by a TTO employee who stated that they are all too busy protecting the IP and so there is no time for further activities. The time issue was further acknowledge by another TTO manager who said that they spent most of their time protecting IP and do not have enough time to commercialise the IP. This study finds that approximately $50 \%$ of the stakeholders identified the TTO as a barrier to knowledge transfer and do not trust the TTO's abilities. The other half did not necessarily see them as a barrier but appeared to be ambivalent about the role that TTOs play in the process. This latter half felt that the TTOs could not work better given the resources that are provided to them.

PIs also query the role of TTOs in IP protection. "Patents are just lying around and rot" according to one German PI. This occurs as the TTO does not have the personnel with commercialisation abilities. Another German PI demonstrates the negative perception of TTOs as follows:

“my employees said to me 'please just keep the TTOs off our backs'...the problem with the TTOs in Germany, and possibly elsewhere in Europe, is that they got 
established to show success quite quickly. But on the other side they are employed as civil servants and that means they don't profit from their successes...the only thing they can do is peddle their importance... they don't advance things, because they lack the right motivation...they tend to do technological self-gratification and nothing else."

Many academics are not confident in the abilities of their TTOs. One PI questioned the TTO's "capacity to deliver" what PIs want. This lack of capacity to deliver is evident in both Ireland and Germany. It is also present across all universities as all excellence centres have started to employ their own personnel to replicate the TTOs' job within the centres. This in itself shows that TTOs are not perceived as great facilitators.

\section{Discussion}

\subsection{The role of the PI}

The research empirically validates the entrepreneurial role of PIs in building and shaping networks. Scientific research is highly complex, idiosyncratic and difficult to transfer if the inventors are not involved in the process. As the German R\&D manager surmises; 'it's not about universities it about professorships'. In the literature there is strong consensus that collaboration of original researcher and 'customer' are of great importance in the development phase and afterwards (Jolly 1997, Roberts 2000, Thorburn 2000, Jensen and Thursby 2001, Zucker et al. 2002, Knockaert et al. 2009). Industry partners can even become loyal to individual PIs, changing university, to go with the PI, and continue the working relationship. Multiple stakeholders agreed on this issue regardless of organisational size, type and geographical location. It is very clear that the PIs play a leading role, not just in the initiation, but also in the management and maintenance of these relationships. The findings suggest that the PI is best placed to bridge the gap between industry and academia and not the TTO manager, as proposed by several authors (Siegel et al. 2004; Wright et al. 2008).

The research also empirically validates the knowledge spillover theory of entrepreneurship (O'Gorman et al. 2008), where commercialisation of new knowledge via entrepreneurship will occur, when scientists (a) are aware of individual benefits to commercialisation, (b) are able to identify the economic value of new knowledge and (c) have access to external bodies with resources and market knowledge to invest in the new knowledge. 


\subsubsection{The establishment of collaborative relationships and networks}

The study shows the importance of the PIs in initiating the contact with industry. This is achieved by (a) showing their own interest in collaborating, transferring or commercialising knowledge and (b) contributing to their reputation or that of the centre by publishing in high ranking journals. These findings add to prior research on motives for exploiting technology and participating in research. The stakeholder analysis shows that PIs are required by the government, industrial partners and centre managers to show an interest in transferring and commercialising knowledge and to do world class science in order to publish in high ranking journals. The latter requirement is consistent with PIs' motive for recognition within the scientific community (Siegel 2003; Siegel et al. 2003; Siegel et al. 2004). Encouraging an interest in commercialisation, however, is likely to prove much more difficult to achieve, under existing reward structures.

\subsubsection{The management of collaborative relationships within networks}

In terms of management of relationships the findings showed that it is the PI who is responsible for coordinating these relationships and acting as a guardian for evaluating and reconciling mutual interests. Again, the TTO's role was perceived as being less important. Instead, the PI has to be 'a jack of all trades', taking on the roles of project manager, negotiator, resource acquirer, as well as the traditional academic roles of $\mathrm{Ph} . \mathrm{D}$. supervision and mentoring. PIs have to juggle this role with their traditional academic roles and this means that PIs often have to choose between these roles.

\subsection{The role of the TTO}

The findings on the PI's role raise questions about the role of the TTO in establishing links and bridging the gap between academia and industry (Wright et al. 2008, Yusuf 2008). The findings show that the TTOs are generally negatively perceived and do not play the role that is currently expected of them. TTOs are perceived as mainly dealing with the protection of IP and are either unable or have insufficient time and resources to execute the commercialisation of scientific knowledge. This raises the question of whether alternatives should be explored, such as centralising the TTO service or allowing research centres to employ their own technology transfer personnel, a development that is currently evolving in many excellence centres. 
At a minimum the findings suggest that the role of the TTO needs to be re-evaluated and clarified so that it can better support the PIs in their role of establishing and managing collaborative networks.

\subsection{Contextual Differences}

While there are some contextual differences the role of the PI is similarly perceived in both Germany and Ireland. In terms of similarities, the importance of relationships and the need to build collaborative networks is cited as the most important driver for scientific knowledge commercialisation. Both countries criticise the generalised method of applying the American model of spinning out to European systems. Additionally, criticism of TTOs is frequent in both countries.

Research on the context shows, that German industry partners still view PIs as sitting in their 'ivory towers'. Nevertheless, they start collaborative projects with them due to their reputation and knowledge base. In Ireland, on the other hand, industry participation is almost always a requirement for funding. PIs are under pressure to show commercial returns and therefore seek out collaborations. German academics, however, are not under pressure to show commercial results from Government funding. Researching the context shows that the German funding system allows academics to apply for basic science funding and remove themselves from industry collaborations if desired. Nevertheless, if German academics opt for collaborative research activities their role is consistent with their Irish colleagues.

Additionally, the study supports the general idea that excellence centres are established to create internationally visible, competitive research facilities. The study proposes that excellence centres have an advantage over faculties as an aggregation effect is created by virtue of the concentration of a number of PIs in one location. This is not to say that faculties cannot compete and the study cautions against generalising this finding. A single PI can be the critical determinant.

\subsection{Managerial implications}

Given, the central role of the PI in collaborative networks, it would appear important that the PIs are commercially aware. While training PIs could address this issue to a certain extent, 
thought must be given to (a) providing industry experience as part of academic training of PIs and (b) hiring PIs that have industry experience. Bringing PIs with increased levels of commercial awareness into stakeholder networks is likely to enhance the capabilities of those networks and would serve to minimise disconnects between the university and their industry partner. In addition, it is confirmed that serial inventors are role models and crucial to creating an entrepreneurial milieu (Goktepe-Hultèn 2008). Hiring PIs with industry experience, thus, enhances the propensity to create a culture of interest in collaborations for scientific-knowledge commercialisation.

PIs are heavily burdened with research, teaching and administration activities (Sabatier et al. 2006). Engaging in collaborative activities is not highly valued by PIs and when they do engage, their engagement is not significantly rewarded. The findings on the role of PIs, however, suggest that the PI's need to show a willingness to engage in collaborations. The need to encourage PIs to do collaborative research is therefore a managerial implication. Several scholars (Goldfarb and Henrekson 2003, Siegel et al. 2004, Lockett et al. 2008) have already debated the impact of (a) insufficient incentive structures; (b) the university reward system; (c) the preconceived notion of incentives in favour of teaching and publishing; and (d) the lack of recognition of research commercialisation. It is therefore important to take into account that most scientists take part in commercialisation to further their research. The choice to either take the entrepreneurial route or to commercialise research through collaborative projects depends on commercial motives (entrepreneurial route) or researchrelated motives (collaborative projects and TTO route) (D'Este and Perkmann 2010).

Baumol (1990) points outs the allocation of entrepreneurship between productive and unproductive activity depends on laws and regulations, and whilst the supply of entrepreneurs may take a long time to change, reward structures are relatively easily changed. The findings show that you cannot simply force PIs to do collaborations and PIs must be adequately incentivised. Incentives should not be simply thought of in terms of financial incentives. For example, the attraction of freedom to academics should not be understated. Rather than dismissing the desire of academics to work in an autonomous way, this could be a strong incentive in rewarding entrepreneurial behaviour. Those PIs that show a willingness to engage in the commercialisation process should be given this freedom through the relief of other tasks that restrict their academic freedom. Were the role of TTOs to be redefined to 
focus on, for example, reducing the PI's administrative burden then this would allow the PI to work on matters that they want, as opposed to have, to do. Monetary rewards and opportunities for promotion need to be more clearly aligned with the universities third mission. This issue has been highlighted in numerous previous studies but has not been addressed. Until this is addressed then networks will be prevented from maximising commercial returns from scientific knowledge and in some cases the commercialisation process will not commence at all. The failure to align university incentive structures has led to PIs being perceived as stakeholders in their own right, thereby complicating the process of network creation and development.

The role of the TTO in networks of scientific knowledge collaboration is negatively perceived, generally. Proximity to the research projects and knowledge of the particular IP seem necessary for success and favours a more local based support structure. The findings are consistent with those of Colyvas et al. (2002) who noted that the TTO activities are only needed where existing links are weak. At a minimum the results suggest that the role of the TTO needs to be revaluated so that it can better support PIs in their role. This research suggests that PIs are better placed to act as boundary spanners between science and industry.

\section{Bibliography}

Adler, N., Elmquist, M. and Norrgren, F. 2009. The challenge of managing boundary-spanning research activities: Experiences from the Swedish context. Research Policy, 38(7), pp.1136-1149.

Ambos, T.C., Mäkel, K., Birkinshaw, J. and D'Este, P. 2008. When does university research get commercialized? Creating ambidexterity in research institutions. Journal of Management Studies, 45(8), pp.1424-1447.

Audretsch, D.B., Aldridge, T. and Oettl, A. 2006. The knowledge filter and economic growth: The role of scientist entrepreneurship. Jena: Max Planck Institute of Economics, Group for Entrepreneurship, Growth and Public Policy.

Birley, S. 2002. Universities, Academics, and Spinout Companies: Lessons from Imperial. International Journal of Entrepreneurship Education, 1(1), pp.133-154.

Baumol, W.J. 1990. Entrepreneurship, Productive Unproductive and Destructive. Journal of Political Economy, 98 (5), pp. 893-921.

Boardman, P.C. and Corley, E.A. 2008. University research centers and the composition of research collaborations. Research Policy, 37(5), pp.900-913.

Boardman, P.C. 2009. Government centrality to university-industry interactions: University research centers and the industry involvement of academic researchers. Research Policy, 38(10), pp.1505-1516. 
Chapple, W., Lockett, A., Siegel, D. and Wright, M. 2005. Assessing the relative performance of U.K. university technology transfer offices: parametric and non-parametric evidence. Research Policy, 34(3), pp.369384.

Colyvas, J., Crow, M., Gelijns, A., Mazzoleni, R., Nelson, R.R., Rosenberg, N. and Sampat, B.N. 2002. How Do University Inventions Get Into Practice? Management Science, 48(1), pp.61-72.

Commission of Experts for Research and Innovation 2009. Research, innovation and technological performance in Germany. Berlin: EFI.

Debackere, K. and Veugelers, R. 2005. The role of academic technology transfer organizations in improving industry science links. Research Policy, 34(3), pp.321-342.

D'Este, P. and Perkmann, M. 2010. Why do academics engage with industry? The entrepreneurial university and individual motivations. The Journal of Technology Transfer, pp.1-24.

Eisenhardt, K.M. 1989. Agency theory: An assessment and review. The Academy of Management Review, 14(1), pp.57-74.

Eisenhardt, K.M. and Graebner, M.E. 2007. Theory building from cases: Opportunities and challenges. The Academy of Management Journal, 50(1), pp.25-32.

Eurostat 2012.R\&D expenditure of GDP. Luxembourg: Eurostat.

Fontes, M. 2001. A closer look at the process of transformation of scientific and technological knowledge as conducted by academic spin-offs IN: Oakey, R., During, W. and Kauser, S. (eds.) New technology-based firms in the new millennium Vol. II. Amsterdam: Pergamon, pp.47-70.

Forfas 2010. Review of supports for exploitation of intellectual property from higher education research. Dublin: Forfas.

Forfas 2009. Research and development statistics in Ireland 2009 - at a glance. Dublin: Forfas.

Gibbert, M., Ruigrok, W. and Wicki, B. 2008. What passes as a rigorous case study? Strategic Management Journal, 29(13), pp.1465-1474.

Glaser, B. and Strauss, A. 1967. The discovery of grounded theory, Hawthorne, NY: Aldine de Gruyter.

Goktepe-Hultèn, D. 2008. Why and how do scientists commercialize their research? Towards a typology of inventors. 2008 - 071. Jena: Jena Economic Research Papers.

Goldfarb, B. and Henrekson, M. 2003. Bottom-up versus top-down policies towards the commercialization of university intellectual property. Research Policy, 32(4), pp.639-658.

Halinen, A. and Tornroos, J.A. 2005. Using case methods in the study of contemporary business networks. Journal of Business Research, 58pp.1285-1297.

Hall, Z.W. 2004. The academy and industry. A view across the divide IN: Stein, D.G. (ed.) Buying in or selling out?: The commercialization of the American research university. New Brunswick Rutgers University Press, pp.153-160.

Harmon, B., Ardishvili, A., Cardozo, R., Elder, T., Leuthold, J., Parshall, J., Raghian, M. and Smith, D. 1997. Mapping the university technology transfer process. Journal of Business Venturing, 12(6), pp.423-434.

INSEAD 2011.The global innovation index 2011.Fontainebleau: INSEAD. 
Jensen, R. and Thursby, M. 2001. Proofs and prototypes for sale: The licensing of university inventions. American Economic Review, 91(1), pp.240-259.

Jolly, V.K. 1997. Commercializing new technologies: Getting from mind to market. 3rd ed. Massachusetts: Harvard Business School Press.

Jones-Evans, D. and Klofsten, M. 1999. Creating a bridge between university and industry in small European countries: The role of the.. $R \& D$ Management, 29(1), pp.47.

Jordan, D. and O'Leary, E. 2007. Is Irish innovation policy working? Evidence from Irish high-technology businesses. Dublin: Paper presented to a Meeting of the Statistical and Social Inquiry Society of Ireland on 25th October 2007.

Kienbaum Managment Consultants GmbH (2006) Weiterentwicklung von Kriterien sowie Datenerhebung auf Basis der Kriterien und Datenauswertung bezueglich der Kompetenz und Leistungsfaehigkeit der Patent- und Verwertungsagenturen. Abschlussbericht im Auftrag des BMBFI

Knockaert, M., Ucbasaran, D., Wright, M. and Clarysse, B. 2009. How does tacit knowledge transfer influence innovation speed? The case of science based entrepreneurial firms. 2009/554. Gent: Working Paper Universiteit Gent.

Lambert, R. 2003. Lambert Review of University-Business Collaboration. Norwich: HM Stationery office.

Lockett, A., Siegel, D., Wright, M. and Ensley, M.D. 2005. The creation of spin-off firms at public research institutions: Managerial and policy implications. Research Policy, 34(7), pp.981-993.

Lockett, N., Kerr, R. and Robinson, S. 2008. Multiple perspectives on the Challenges for knowledge transfer between higher education institutions and industry. International Small Business Journal, 26(6), pp. 661-681.

Martinelli, A., Meyer, M. and von Tunzelmann, N. 2008. Becoming an entrepreneurial university? A case study of knowledge exchange relationships and faculty attitudes in a medium-sized, research-oriented university. The Journal of Technology Transfer, 33(3), pp.259-283.

Meyer, M. 2003. Academic entrepreneurs or entrepreneurial academics? research-based ventures and public support mechanisms. $R \& D$ Management, 33(2), pp.107-115.

Miles, M.B. and Huberman, A.M. 1994. Qualitative data analysis. London: Sage.

OECD 2002. Turning science into business - patenting and licensing at public research organisations. Paris: OECD.

O’Gorman, C., Byrne, O. and Pandya, D. 2008. How scientists commercialise new knowledge via entrepreneurship. The Journal of Technology Transfer, 33(1), pp.23-43.

O'Shea, R., Allen, T.J., O'Gorman, C. and Roche, F. 2004. Universities and technology transfer: A review of academic entrepreneurship literature. Irish Journal of Management, 25(2), pp.11-29.

O'Shea, R., Chugh, H. and Allen, T. 2008. Determinants and consequences of university spinoff activity: a conceptual framework. The Journal of Technology Transfer, 33(6), pp.653-666.

Oliver, A.L. 2004. Biotechnology entrepreneurial scientists and their collaborations. Research Policy, 33(4), pp.583-597.

Perkmann, M. and Walsh, K. 2009. The two faces of collaboration: impacts of university-industry relations on public research. Industrial and Corporate Change, 18(6), pp.1033-1065. 
Perry, C. 2001. Case research in marketing. Marketing Review, 1(3), pp.303.

Plewa, C. and Quester, P. 2008. A dyadic study of "champions" in university-industry relationships. Asia Pacific Journal of Marketing and Logistics, 20(2), pp.211-226.

Radosevitch, R. 1995. A model for entrepreneurial spin-offs from public technology sources. International Journal of Technology Management, 10(7/8), pp.879-893.

Roberts, E.B. 1991. Entrepreneurs in High Technology: Lessons from MIT and Beyond. Oxford University Press, USA.

Rocks, S., Carson, D. and Gilmore, A. 2007. Understanding small buiness enterprise networking: a qualitative case approach IN: Hine, D. and Carson, D. (eds.) Innovative methodologies in enterprise research. Cheltenham Edward Elgar, pp.214-231.

Rothaermel, F.T., Agung, S.D. and Jiang, L. 2007. University entrepreneurship: a taxonomy of the literature. Industrial and Corporate Change, 16(4), pp.691-791.

Sabatier, M., Carrere, M. and Mangematin, V. 2006. Profiles of Academic Activities and Careers: Does Gender Matter? An Analysis Based on French Life Scientist CVs. Journal of Technology Transfer, 31(3), pp.311-324.

Sellenthin, M.O. 2009. Technology transfer offices and university patenting in Sweden and Germany. The Journal of Technology Transfer, 34(6), pp.603-620.

Siegel, D.S., Waldman, D.A., Atwater, L.E. and Link, A.N. 2003. Commercial knowledge transfers from universities to firms: improving the effectiveness of university-industry collaboration. The Journal of High Technology Management Research, 14(1), pp.111-133.

Siegel, D.S., Waldman, D.A., Atwater, L.E. and Link, A.N. 2004. Toward a model of the effective transfer of scientific knowledge from academicians to practitioners: qualitative evidence from the commercialization of university technologies. Journal of Engineering and Technology Management, 21(1-2), pp.115-142.

Siegel, D. 2003. Data requirements for assessing the private and social returns to strategic research partnerships: Analysis and recommendations. Technology Analysis \& Strategic Management, 15(2), pp.207.

Spilling, O.R. 2004. Commercialisation of knowledge - A conceptual framework. NCSB 2004 Conference, 13th Nordic Conference on Small Business Research: Troms $\emptyset$.

Thorburn, L. 2000. Knowledge management, research spinoffs and commercialization of R\&D in Australia. Asia Pacific Journal of Management, 17(2), pp.257-275.

Voss, C., Tsikriktsis, N. and Frohlich, M. 2002. Case research in operations management. International Journal of Operations \& Production Management, 22(2), pp.195-219.

Wright, M., Clarysse, B., Lockett, A. and Knockaert, M. 2008. Mid-range universities' linkages with industry: Knowledge types and the role of intermediaries. Research Policy, 37(8), pp.1205-1223.

Yin, R.K. 2009. Case study research: design and methods. 4th ed. Thousand Oaks, Calif.: Sage Publications.

Yusuf, S. 2008. Intermediating knowledge exchange between universities and businesses. Research Policy, 37(8), pp.1167-1174.

Zhao, F. 2004. Commercialization of research: a case study of Australian universities. Higher Education Research \& Development, 23(2), pp.223. 
Zucker, L.G., Darby, M.R. and Armstrong, J.S. 2002. Commercializing knowledge: University science, knowledge capture, and firm performance in biotechnology. Management Science, 48(1), pp.138-153. 